\title{
Aphanomyces invadans, the causal agent of Epizootic Ulcerative Syndrome, is a global threat to wild and farmed fish
}

\author{
Nurul Aqilah Iberahim ${ }^{\mathrm{a}, \mathrm{b}, \mathrm{c}}$, Franziska Trusch ${ }^{\mathrm{a}, \mathrm{b}}$ and Pieter van West $\mathrm{W}^{\mathrm{a} \mathrm{b}^{*}}$
}

\footnotetext{
${ }^{a}$ Aberdeen Oomycete Laboratory, Institute of Medical Sciences, University of Aberdeen, Aberdeen, AB25 2ZD, Scotland, United Kingdom.

${ }^{\mathrm{b}}$ International Centre for Aquaculture Research and Development (ICARD), University of Aberdeen, Scotland, United Kingdom.

${ }^{c}$ School of Fisheries and Aquaculture Sciences, Universiti Malaysia Terengganu, 21030, Malaysia
}

\section{*CORRESPONDING AUTHOR}

Prof. Pieter van West: p.vanwest@abdn.ac.uk; +44 (0)1224 437327; +44 (0)1224 437465

\begin{abstract}
Aphanomyces invadans is a eukaryotic pathogen and the causative agent of Epizootic Ulcerative Syndrome (EUS) in fish and is responsible for mortalities of up to $100 \%$ in aquaculture. A. invadans was first discovered in Japan in 1971, and since then it has been found in Australia, North America, Southern African countries and Asia. Methods for the correct identification of $A$. invadans are well established now and involve PCR-based detection and microscopy. However, the pathogenesis of $A$. invadans is poorly understood. Environmental stress (mainly temperature) and the associated immunocompromised fish seem to induce infections of $A$. invadans and outbreaks of EUS. Understanding the process of infection in more depth is fundamental for the discovery of novel effective treatments to combat the disease. In this review, we discuss morphological characteristics of $A$. invadans and its pathogenicity as well as various approaches of treatment.
\end{abstract}

Keywords: Aphanomyces invadans, EUS, EGA, oomycete, aquaculture 


\section{INTRODUCTION}

In times of a rapidly increasing world population, food resources and security become critically important and pathogens infecting crops and farmed animals are coming into focus in the aquaculture industry and in quaranteen departments. A major problem for the agri- as well as aquaculture industry are animal and plant pathogenic oomycetes, which are also responsible for the destruction of many natural host populations (van West, 2006). Oomycetes are eukaryotic pathogens that belong to the Stramenopile Kingdom and are thus genetically related to brown algae but are morphologically similar to fungi (Baldauf et al., 2000; Gleason et al., 2018). A common infection of freshwater and brackish fish species is Epizootic Ulcerative Syndrome (EUS), which is caused by the oomycete Aphanomyces invadans. This water mould threatens especially the aquaculture industry in the Asia-Pacific region. $A$. invadans was first described in 1971 during an outbreak in a freshwater fish farm in Japan (Egusa and Masuda, 1971; Oidtmann, 2012). Since then, outbreaks of EUS have become more frequent and disseminated worldwide including Asia, Australia, North America and more recently Africa (Fig. 1, Tab. 1).

A. invadans was originally declared as an invasive fungus called Aphanomyces invaderis (Willoughby et al., 1995) that was able to produce clinical signs of EUS (Lilley and Roberts, 1997). Later, it was referred to as Aphanomyces piscicida (causing mycotic granulomatosis), Aphanomyces sp (causing red spot disease (RSD)) (Lilley and Roberts, 1997) or simply called EUS-related Aphanomyces (ERA) (Lumanlam-Mayo et al., 1997). Recently, it was proposed to change the name of the disease from EUS to Epizootic granulomatous aphanomycosis (EGA) (Baldock et al., 2005; OIE, 2017). However, so far the term EUS seems to be preferred when (Kamilya and Baruah, 2014) describing the ulcerative disease caused by $A$. invadans. Together with $A$. frigidophilus, $A$. astaci and $A$. stellatus (Diéguez-Uribeondo et al., 2009) $A$. invadans, belongs to the genus Aphanomyces which is beside Saprolegnia the second group in the Saprolegniaceae family within the phylum Oomycota. Besides animal pathogens, this genus also contains plant parasitic and saprotrophic/opportunistic species (Fig. 2). Interestingly, not all isolates of $A$. invadans seem to be pathogenic on fish. A strain naturally occurring in water bodies in Malaysia neither induces an infection in the natural environment nor under laboratory conditions (Afzali et al., 2013).

So far eighty-seven different fish genera were reported to be affected by EUS (Kamilya and Baruah, 2014) with Chana and Puntius being affected the most (Kar, 2016; Lilley et al., 1992). Generally, bottom-dwelling fish like murrels (Chondar and Rao, 1996) or catfishes (Roberts et al., 1994) seem to be highly susceptible. While the size of the fish does not determine an EUS 
outbreak (Cruz-lacierda and Shariff, 1995), younger fish seem to be more prone to EUS compared to adult fish (Gomo et al., 2016; Pagrut et al., 2017).

Recently, the genome of a fish pathogenic strain of $A$. invadans was completely sequenced by the Broad Institute. This allows us to mine for the genes for enzymes such as proteases, effector proteins and other proteins important in pathology (discussed in more detail below). As the global dissemination of $A$. invadans seems to be difficult to prevent, molecular research in this area, now facilitated through the availability of genome sequences, is forging ahead. Therefore, we summarise the current knowledge about this emerging oomycete, including in depth discussion of morphological characteristics, pathogenicity as well as various control strategies.

\section{LIFE CYCLE OF A. INVADANS}

A. invadans passes through the typical life stages of an oomycete without the sexual stage which is often rare or absent in animal-pathogenic oomycetes (Dick et al., 1999). In contrast, the asexual stage is distinctive for the genus Aphanomyces, which is characterized by the formation of biflagellate zoospores from clusters of primary cysts at hyphal tips (DiéguezUribeondo et al., 2009).

Aphanomyces spp. propagate asexually by the formation of zoosporangia comprising 30 to 50 primary zoospores which are released through a lateral evacuation tube into the environment (Hawke et al., 2003). Interestingly, isolates from the Philippines can have up to 2 lateral evacuation tubes per sporangium (Baruah et al., 2012) and isolates from Thailand have normally 4 tubes per sporangium (Callinan et al., 1995).

After release from sporangia, primary zoospores immediately encyst at the apical tip and form achlyoid clusters (Fig. 3). From these clusters secondary zoospore are released which are the main free-swimming stage (movie S1). Later, secondary zoospores transform into a germling by forming a germ tube, which eventually develops into mycelium (Olson et al., 1984; Willoughby et al., 1995). However, encysted zoospores of parasitic Aphanomyces species are capable of releasing a new zoospore generation instead of germinating (Diéguez-Uribeondo et al., 2009). This process is called repeated zoospore emergence (RZE) or polyplanetism (Diéguez-Uribeondo et al., 1994).

Mycelium of Aphanomyces species is cylindrical hyphoid and coenocytic. Hyphae in infected fish show only limited branching with a variable diameter of 6 up to $27 \mu \mathrm{m}$ but are considerably 
narrower under culture conditions (Roberts et al., 1993). At later stages of infection, $A$. invadans also produces vegetative hyphae, sporangia with primary zoospores and spore clusters (Diéguez-Uribeondo et al., 2004; Roberts et al., 1993). Sporulation of A. invadans occurs in waters of low salinity, between 0 and 8 psu (practical salinity unit $5 \%$ ), depending on species, with maximal sporulation at $25^{\circ} \mathrm{C}$ and no sporulation at $30^{\circ} \mathrm{C}$ (Kiryu et al., 2005).

\section{PATHOGENICITY OF A. INVADANS}

\subsection{Clinical symptoms}

Under normal conditions skin defence mechanism of fish are sufficient to prevent an infection with $A$. invadans. However, a suppression of the immune system can result in an outbreak of EUS. Various environmental determinants such as colonisation of the fish by other pathogens (viruses, bacteria or ectoparasites), a low pH or low oxygen concentrations in the water can affect primary defence mechanisms of fish (Kiryu et al., 2005). Under appropriate conditions, some $A$. invadans isolates are capable of acting as a primary pathogen (Sanaullah et al., 2001).

Infections of fish by $A$. invadans are initiated by attachment of motile zoospores. They are attracted to their host, attach to the damaged skin and form germination tubes that penetrate the skin. Hyphae invade deep into lower tissues resulting in extensive ulceration and destruction of the tissue (OIE, 2017, 2009). The typical signs of ulceration can be used as a presumptive diagnosis for EUS on affected fish (Bondad-Reantaso et al., 1992). The occurrence of skin lesions varies depending on the fish species as well as manifestation and ranges from crucial areas of intense inflammation and hyperaemia of the skin to deep ulcerations with uncovering of the lower muscle tissue (Huchzermeyer et al., 2018). Early lesions are characterized by haemorrhagic bullae with small foci of ulceration and are often observed on the lateral surface (Hawke et al., 2003; OIE, 2017; Pathiratne and Rajapakshe, 1998; Yadav et al., 2014). Concomitantly, scales are often protruding. In contrast, lesions in bluegills are characterised by proliferative tan areas on the skin which are associated with scale loss (Hawke et al., 2003). Mildly infected fish show only minor inflammation without external lesions but petechial haemorrhagic spots on body, mouth as well as anal fin and exophtalmia. In severe cases, swollen haemorrhagic areas, massive inflammation and large deep ulcerations in association with necrosis of the myotome can be observed (Pathiratne and Rajapakshe, 1998; Yadav et al., 2014). Ulcers appear as white areas on the skin of the fish with reddish centres that turn into complete red areas and later result in external haemorrhages and distended abdomens. As the disease progresses, eyes are protruding, the body becomes putrefactive and in some cases also the head is eroded, which results in the 
death of fish due to the severity of the disease (Hawke et al., 2003; Podeti and Benarjee, 2017).

\subsection{Pathology}

An infection with $A$. invadans is histologically characterised by severe necrosis of the muscle tissue around the invading hyphae which later develop into enclosed granulomas (Wada et al., 1994). Whereas non-invasive aseptic hyphae with a smaller diameter are frequently observed at the surface of the site of infection (Huchzermeyer et al., 2018; Yadav et al., 2014). Migrating hyphae are observed along fascial layers and between myofibrils where they cause myconecrosis (Chinabut et al., 1995; Pradhan et al., 2008). The severe lesions attract large numbers of inflammatory cells which results in oedema and hyperplasia of gill lamella, but only marginal changes of internal organs (Bondad-Reantaso et al., 1992).

Most of the haematological data revealed that fish with EUS show a significant increase of white blood cells (especially neutrophils) due to a local inflammatory response (Pathiratne and Rajapakshe, 1998; Qureshi et al., 2001), while the number of red blood cells, the haemoglobin concentration and the haematocrit level are reduced because of the blood loss caused by the haemorrhagic lesions (Das and Das, 1993; Pathiratne and Rajapakshe, 1998; Podeti and Benarjee, 2017, 2015). The combination of an increase of neutrophils and a reduction of erythrocytes (including haematocrit and haemoglobin content) shows that $A$. invadansinfected fish suffer from anemic condition.

\subsection{Effector proteins}

A generally accepted model how oomycetes successfully establish an infection of their host is the secretion of so called effector proteins. Effector proteins are released during the infection and they target host factors to overcome host defence mechanisms or they adapt the host metabolism for the pathogen's benefit. Recently, an A. invadans genome (strain NJM9701) was sequenced (Aphanomyces WGS initiative, Broad Institute (broadinstitute.org)) including its mitochondrial genome (Makkonen et al., 2016) with Illumina sequencing technology (Genbank Accession PRJNA188082). Initial analysis using FungiDB (http://fungidb.org/fungidb/) shows that the genome has a good repertoire of effector proteins that are predicted to interact with various host processes (Tab. 2). As expected the effector repertoire shows more similarities to the fish-pathogenic $S$. parasitica than to the plantpathogenic $P$. infestans. As in $S$. parasitica, in $A$. invadans, the so called RxLR and CRN effectors are absent and seem to be unique to the plant pathogenic Phytophthora species. In line with a previous report on active proteases of $A$. invadans secreted into the culture filtrate is the high number of predicted proteases in the genome (Majeed et al., 2017). Interestingly, 
the $A$. invadans genome lacks disintegrins as well as haemolysin-E and codes for fewer Ricinlike proteins, when compared to $S$. parasitica.

\section{IDENTIFICATION OF A. INVADANS}

In the past it was very challenging to identify Aphanomyces sp. correctly because of the difficult procedures for isolation and conditions for growth in culture (Hawke et al., 2003). These days, beside clinical signs of EUS infected fish, molecular methods are also used to identify Aphanomyces sp.

\subsection{PCR-based}

A very sensitive and specific technique is ITS sequencing (Internal Transcribes Spacer) which is widely used for the molecular identification and differentiation of oomycetes from species to genus level (Gozlan et al., 2014; Hart, 1997; Huchzermeyer et al., 2018; Leclerc et al., 2000; J. Lilley et al., 2003; J. H. Lilley et al., 2003; Phadee et al., 2004; Robideau et al., 2011; Takuma et al., 2010; Vandersea et al., 2006). The three main lineages of $A$. invadans (Fig. 2) can be also distinguished by ITS sequencing (Diéguez-Uribeondo et al., 2009).

In addition, restriction fragment length polymorphisms (RFLPs) and sequences of ribosomal DNA (rDNA) were used to distinguish $A$. invadans from other species including saprolegniacaea (Lilley et al., 2003).

Recently, also the mitochondrial gene cytochrome c oxidase subunit I (COI) was used for the identification of Aphanomyces species. The mitochondrial genome was sequenced recently and found to be 49,061 basepairs long and has a large inverted repeat region of about $12 \mathrm{~kb}$ (Makkonen et al., 2016). Comparison of ITS and COI sequences of 23 oomycete genera including Aphanomyces sp. revealed, that both are suitable for the identification of oomycetes but in some cases $\mathrm{COI}$ was more discriminative than ITS at the species level. However, COI sequences are not conserved throughout all Aphanomyces species (Robideau et al., 2011).

\subsection{Microscopy-based}

Mycelia-like structures and zoospores of $A$. invadans can be detected by in-situ hybridisation (FISH) (OIE, 2009; Vandersea et al., 2006) or immunofluorescent staining on histological sections of infected fish (Devaraja et al., 2004; Miles et al., 2003).

\subsection{Immunological methods}


Various immunological methods were established to reliably identify $A$. invadans with a very high sensitivity $\left(7 \mu \mathrm{g} / \mathrm{ml}\right.$, dilutions up to $\left.10^{-11}\right)$ such as FTA (Monoclonal antibody-based flowthrough immunoassay, (Adil et al., 2013)) or immunoblots (Ganapathi et al., 2008; Miles et al., 2003).

\section{CAUSATIVE AGENT OF EUS}

Zoospores of $A$. invadans from infected tissues can be captured with a baiting method (Afzali et al., 2013; Kiziewicz et al., 2011). Although A. invadans is the causative agent of EUS (Huchzermeyer and Van der Waal, 2012), also other pathogenic viruses (mostly rhabdovirus), bacteria (mainly Aeromonas hydrophila) or parasitic protozoans are routinely co-isolated from A. invadans-infected fish (Tab. 3). However, no evidence currently exists confirming that these organisms are causally contributing to EUS disease (John and George, 2012). Parasitic infections possibly induce stress in fish and thereby might predisposing them to infection (Subasinghe, 1993).

\section{EUS OUTBREAKS}

\subsection{Outbreaks in nature}

Since the defence system of fish has to be supressed in order to be infected by $A$. invadans, a major focus of research lies on the environmental conditions triggering an EUS outbreak. Under laboratory conditions the optimal growth temperature for $A$. invadans is between 19-22 ${ }^{\circ} \mathrm{C}$, while under natural conditions $A$. invadans seems to be more robust (Hawke et al., 2003). Some EUS outbreaks are associated with heavy rainfall and flood events that can cause a sudden drop in temperature from $20^{\circ} \mathrm{C}$ to $10-15^{\circ} \mathrm{C}$ (Bondad-Reantaso et al., 1992; Choongo et al., 2009; Go et al., 2012; Hawke et al., 2003; Lilley and Roberts, 1997). Since fish are poikilothermic organisms and do not control their body temperature, a decrease of the environmental temperature automatically results also in a drop of the body temperature (Ernst et al., 2016). Indeed, it was shown in infected snakeheads (Channa striatus) that the inflammatory cell response is reduced with a decrease in temperature which likely delays the inflammatory response of the fish to an infection (Catap and Munday, 2002; Chinabut et al., 1995). In addition, a reduced temperature also favours the sporulation of $A$. invadans (Lumanlam-Mayo et al., 1997). However, a series of EUS outbreaks was reported in relation to a temperature increase in Southeastern Louisiana (Hawke et al., 2003) and India (Pradhan et al., 2014). It was observed that hyphae grow actively outside the body on the surface around lesions at higher temperatures, while they invade deeper into fish tissues at $20^{\circ} \mathrm{C}$ (Kar, 2016). 
Most EUS outbreaks occur in slightly acidic water ( $\mathrm{pH}$ 6.0-7.0) on sandy soil with low levels of alkalinity, hardness and chlorides (Choongo et al., 2009; Hawke et al., 2003). Generally, A. invadans is quite resistant to environmental stress, such as high salinity or variable temperatures and can also survive in high alkaline condition and harder water (Das and Das, 1993; Pradhan et al., 2014). In contrast, extremely high or low pH values cause damage to fish tissues, especially the gill and the epidermis which reduces the resistance to potential infections (Svobodova et al., 1993; Thampuran et al., 1995).

To understand EUS it is important to have a model system ready which allows to copy an infection of a fish by $A$. invadans under controlled laboratory conditions. Zoospores of $A$. invadans are produced by incubating mycelium in starvation medium. The isolated zoospores, transmitted by injection or immersion, will attach to the host and initiate the infection and reproduction process (Kiryu et al., 2002). Artificial infections of fish by injection show clinical signs comparable to natural infections, including localised swelling and reddening. On day 4 scale loss and ulceration of lower musculature appear which develop into deep ulceration as the disease progresses (Afzali et al., 2015). Histopathological features of moribund and dead fish were also the same as for fish with EUS collected from the wild (Pradhan et al., 2010).

\subsection{Global trade and spread of EUS}

Globalisation and the involved global trading is a major amplifier for the dissemination of pathogens worldwide. Thus, by increasing import activities EUS is also transmitted to EUS free countries such as Europe (EFSA Panel on Animal Health and Welfare, 2011). Around 4000 freshwater species from farms and 1400 wild-caught marine species of ornamental fish or pet fish are traded internationally from tropical countries per annum. (Whittington and Chong, 2007).

Skin lesion infections of ornamental fishes were reported in several pet shops in Germany which were confirmed by PCR to be caused by $A$. invadans. The infected fish were Blue gourami (Trichogaster trichopterus) from Thailand, Cardinal tetra (Paxelrodi) from Brazil and Dwarf gourami (Colisa lalia) from Vietnam. The results are quite alarming as the traded fish comes with a certificate from the country of origin stating EUS-free (El-Matbouli et al., 2014). An outbreak of an $A$. invadans infection in Japan was also found in the pet fish Dwarf gourami (Colisa lalia) imported from Singapore (Hatai et al., 1994; Wada et al., 1994) and Golden gourami (Hanjavanit et al., 1997). All reported fish have shown the typical clinical signs of EUS including haemorrhagic, dermal swelling and scale loss.

A similar case was also described for the Pseudorasbora parva (topmouth gud-geon) carrying Sphaerothecum destruens whereby $S$. destruens was able to invade natural river system in more than 30 countries (Gozlan et al., 2010). 


\section{TREATMENT STRATEGIES}

Since $A$. invadans has a major impact on the aquaculture industry especially in Asian countries, a lot of research is done in the area of treatment of EUS and how to prevent infections with $A$. invadans. Unfortunately, the treatment options are limited at present.

\subsection{Chemicals and antibiotics}

Treatment with Malachite green (which has been banned, worldwide) and formalin are to date the most effective ways to prevent EUS because mycelium as well as zoospores of $A$. invadans are killed at very low concentrations (Afzali and Wong, 2017; Campbell et al., 2001; Lilley and Inglis, 1997) but are hazardous to farm workers and the environment (Srivastava et al., 2004). Also exposure of the fish to $\mathrm{H}_{2} \mathrm{O}_{2}$ and $20 \% \mathrm{NaCl}$ for 1 hour were shown to be capable to kill $A$. invadans isolates (Lilley and Inglis, 1997).

Another treatment strategy is the application of chitosan into fish food. A challenge of fish with A. invadans fed with and without chitosan supplemented food resulted in a significantly lower cumulative mortality of chitosan-treated fish (Shanthi Mari et al., 2014).

Also $\mathrm{ZnO}_{3}$ nanoparticles and $\mathrm{ClO}_{2}$ have shown promising toxiticity against $A$. invadans but no challenge experiments were performed yet (Borisutpeth et al., 2010; Shaalan et al., 2017).

No sufficiently effective antibiotics have been described to kill $A$. invadans. Streptomycin had the strongest effect and reduced $A$. invadans growth by $70-100 \%$ at a concentration of 500ppm (Lilley and Inglis, 1997).

\subsection{Plant extracts}

Interestingly, extracts of a whole range of various plants were successfully tested against $A$. invadans (Tab. 4). But also single compounds from Azadirachta indica, Ocimum sanctum, Curcuma longa like azadirachtin, camphor, and curcumin, respectively have been shown to successfully protect fish against an infection with $A$. invadans when injected intramuscularly or used in fish food (Harikrishnan et al., 2009). Another compound (eugenol) extracted from clove oil was very effective against $A$. invadans. However, eugenol is also very toxic for salmonids and to a lesser extent to cyprinids (Hussein et al., 2000).

\subsection{Immunostimulants}

Immunostimulants are substances that stimulate the immune system by inducing its activation or increasing its activity of any of its components and therefore a potential way to counterbalance immunosuppression by stress or decreased environmental temperatures.

Vitamin $C$ was shown to have an immunostimulative effect because it increased the total number of white blood cells which improves the handling of stress by fish, including improved 
resistance against infections and faster recovery from stress situations (Innocent et al., 2011). The commercial immunostimulant Salar-bec comprising several vitamins reduces the spread of mycelium on the fish body and induces the formation of granulomata to limit spread of the infection on the fish (Miles et al., 2001), which are a main characteristic of EUS resistant fish species (Chinabut et al., 1995; Wada et al., 1996).

Also the addition of fish oil as a source of lipid to fish diets can reduce the effect of a temperature drop on the immune response by improving the membrane fluidity (Ernst et al., 2016).

Ethanol extracts of Solanum nigrum can be also immunostimulative and thereby preventing fish disease and reduce the mortality by up to $20 \%$ (Abu et al., 2017) while water-based extracts did not show any effect (Haniffa et al., 2011).

Recently, the metal-based compound Zeolite was shown to enhance the immunological response and disease resistance against $A$. invadans as well as growth of the fish (Jawahar et al., 2016)

\subsection{Vaccination}

Vaccination of fish against $A$. invadans had thus far only limited success. Vaccination trials have been based on protein extracts made from $A$. invadans hyphae (Saikia and Kamilya, 2012). In this study, vaccination was done in combination with an adjuvant which significantly increases the antibody production and activates components of the innate immunity. Although a reduction in mortality was demonstrated in challenged fish, it was not statistically significant.

\section{FUTURE PERSPECTIVES}

In the last 5 decades $A$. invadans is disseminating increasingly faster and is now found worldwide, which is probably due to the globalisation and maybe even climate change (Fig. 1). While significant progress was made regarding diagnostics of $A$. invadans, limited perspectives for control strategies exist at present.

It is clear from the research reviewed that treatment using various plant extract, chemicals and antibiotics were widely tested, but most of them are only applicable under controlled laboratory conditons in small scales. In addition, the utilisation of drugs and antibiotics in aquaculture is highly regulated to avoid safety risks to the public and the environment and to prevent the development of resistant strains of pathogens. Therefore, farmers are often left without any reliable preventive plans.

Biotechnology and molecular techniques have proven to deliver successful tools to control diseases (Alvarez et al., 2004) but not for $A$. invadans as of yet. The genome of $A$. invadans 
has been sequenced (Aphanomyces WGS initiative, Broad Institute (broadinstitute.org)) and will form the starting point for future studies towards understanding the biology of $A$. invadans. Now genome editing and gene silencing or mutagenesis systems such as RNAi or CRISPR/Cas are urgently required to functionally characterise genes. We anticipate that detailed molecular studies of the host-pathogen interaction will ultimately provide new targets for the development of novel therapeutics. However, it is extremely important that agricultural scientists take the threat of the spread of Aphanomyces seriously and that industry and governments provide adequate funding for research into preventative measures.

\section{ACKNOWLEDGEMENTS}

Our work is supported by the University of Aberdeen (PvW); BBSRC (BB/M026566/1 \& BB/P020224/1: PvW); BBSRC (BB/N005058/1 \& BB/J018333/1: FT \& PvW); NERC (NE/P010873/1: PvW) and a PhD scholarship from Ministry of Education Malaysia (NAI). 


\section{REFERENCES}

Abu, M., Nyeem, B., Mamun, A., Rashid, U., Nowrose, M., Hossain, M.A., Abu, C.M., 2017. Solanum nigrum (Maku): A review of pharmacological activities and clinical effects. Int. J. Appl. Res. 3, 12-17.

Adil, B., Shankar, K.M., Naveen Kumar, B.T., Patil, R., Ballyaya, A., Ramesh, K.S., Poojary, S.R., Byadgi, O. V., Siriyappagouder, P., 2013. Development and standardization of a monoclonal antibody-based rapid flow-through immunoassay for the detection of Aphanomyces invadans in the field. J. Vet. Sci. 14, 413-419. https://doi.org/10.4142/jvs.2013.14.4.413

Afzali, S.F., Abdul-Rahim, H., Sabri, J., 2013. Isolation and identification of Aphanomyces species from natural water bodies and fish farms in Selangor, Malaysia. Malays. Appl. Biol 42, 21-31.

Afzali, S.F., Mohd Daud, H.H., Sharifpour, I., Afsharnasab, M., Shankar, S., 2015. Experimental infection of Aphanomyces invadans and susceptibility in seven species of tropical fish. Vet. World 8, 1038-1044. https://doi.org/10.14202/vetworld.2015.1038-1044

Afzali, S.F., Wong, W.L., 2017. In vitro screening of Sonneratia alba extract against the oomycete fish pathogen, Aphanomyces invadans. Iran. J. Fish. Sci. 16, 1333-1340.

Ahne, W., Jørgensen, P.E. V., Olesen, N.J., Wattanavijarn, W., 1988. Serological examination of a rhabdovirus isolated from snakehead (Ophicephalus striatus) in Thailand with ulcerative syndrome. J. Appl. Ichthyol. 4, 194-196. https://doi.org/10.1111/j.1439-0426.1988.tb00562.x

Alvarez, E., Llano R., G.A., Loke, J.B., Mejía De Los Rios, J.F., 2004. Applying biotechnology tools to improve control diseases of some tropical crops. Fitopatol. Colomb. 28, 93-97.

Andrew, T.G., Huchzermeyer, K.D.A., Mbeha, B.C., Nengu, S.M., 2008. Epizootic ulcerative syndrome affecting fish in the Zambezi river system in southern Africa. Vet. Rec. 163, 629-31.

Baldauf, S.L., Roger, A.J., Wenk-Siefert, I., Doolittle, W.F., 2000. A kingdom-level phylogeny of eukaryotes based on combined protein data. Science 290, 972-7.

Baldock, F.., Blazer, V., Callinan, R.B., Hatai, K., Karunasagar, I., Mohan, C.V., Bondad-Reantaso, M.G., 2005. Outcomes of a Short Expert Consultation on Epizootic Ulcerative Syndrome ( EUS ): Re-examination of Causal Factors, Case Definition and Nomenclature. Dis. Asian Aquac. V $555-585$

Barua, G., 1994. The status of epizootic ulcerative syndrome of fish of Bangladesh, in: Roberts, R., Campbell, B., MacRae, I. (Eds.), Proceedings of the ODA Regional Seminar on Epizootic Ulcerative Syndrome. Aquatic Animal Health Research Institute, Bangkok, pp. 13-20.

Baruah, A., Saha, R.K., Kamilya, D., 2012. Inter-species transmission of the epizootic ulcerative syndrome (EUS) Pathogen, Aphanomyces invadans, And associated physiological responses. Isr. J. Aquac. - Bamidgeh 64, 9.

Blazer, V.S., Vogelbein, W.K., Densmore, C.L., May, E.B., Lilley, J.H., Zwerner, D.E., 1999. Aphanomyces as a Cause of Ulcerative Skin Lesions of Menhaden from Chesapeake Bay Tributaries. J. Aquat. Anim. Health 11, 340-349. https://doi.org/10.1577/15488667(1999)011<0340:AAACOU>2.0.CO;2

Bondad-Reantaso, M.G., Lumanlan, S.C., Natividad, J.M., Phillips, M.J., 1992. Environmental monitoring of the epizootic ulcerative syndrome (EUS) in fish from Munoz, Nurva Ecija, Philippines, in: Shariff, I.M., Subsasinghe, R.P., Arthur, J.R. (Eds.), Diseases in Asian Aquaculture. Fish Health Section, Asian Fisheries Society, Manila, Philippines, pp. 475-490.

Borisutpeth, M., Kanbutra, P., Weerakhun, S., Wada, S., Hatai, K., 2014. In vitro antifungal activity of cassia fistula L. Against selected pathogenic water molds. Int. J. Phytomedicine 6, 237-242.

Borisutpeth, P., Kanbutra, P., Hanjavanit, C., Chukanhom, K., Funaki, D., Hatai, K., 2009. Effects of Thai Herbs on the Control of Fungal Infection in Tilapia Eggs and the Toxicity to the Eggs. Aquac. Sci. 57, 475-482. https://doi.org/10.11233/aquaculturesci.57.475

Borisutpeth, P., Kanbutra, P., Hanjavanit, C., Horiuchi, E., Wada, S., Hatai, K., 2010. The In Vitro Antifungal Effects of Chlorine Dioxide on Water Molds. Aquac. Sci. 58, 219-224. https://doi.org/10.11233/aquaculturesci.58.219

Boys, C.A., Rowland, S.J., Gabor, M., Gabor, L., Marsh, I.B., Hum, S., Callinan, R.B., 2012. Emergence of epizootic ulcerative syndrome in native fish of the murray-darling river system, Australia: Hosts, distribution and possible vectors. PLoS One 7, e35568. https://doi.org/10.1371/journal.pone.0035568

Callinan, R.B., Chinabut, S., Kanchanakhan, S., Lilley, J.H., Phillips, M.J., 1997. Epizootic ulcerative syndrome (EUS) of fishes in Pakistan, A report of the finding of a mission to Pakistan on 9-19 March 1997.

Callinan, R.B., Paclibare, J.O., Bondad-Reantaso, M.G., Chin, J.C., Gogolewski, R.P., 1995. Aphanomyces species associated with epizootic ulcerative syndrome (EUS) in the Philippines 
and red spot disease (RSD) in Australia: Preliminary comparative studies. Dis. Aquat. Organ. 21, 233-238. https://doi.org/10.3354/dao021233

Campbell, R.E., Lilley, J.H., Taukhid, Panyawachira, V., Kanchanakhan, S., 2001. In vitro screening of novel treatments for Aphanomyces invadans. Aquac. Res. 32, 223-233.

https://doi.org/10.1046/j.1365-2109.2001.00551.x

Catap, E.S., Munday, B.L., 2002. Development of a method for reproducing epizootic ulcerative syndrome using controlled doses of Aphanomyces invadans in species with different salinity requirements. Aquaculture 209, 35-47. https://doi.org/10.1016/S0044-8486(01)00805-5

Chandrakanthi, W.H.S., Pathiratne, A., Widanapathirana, G.S., 2000. Characteristics and virulence of Aeromonas Hydrophila isolates from freshwater fish with epizootic ulcerative syndrome (EUS). J. Natl. Sci. Found. Sri Lanka 28, 29-42.

Chinabut, S., Roberts, R.J., Willoughby, G.R., Pearson, M.D., 1995. Histopathology of snakehead, Channa striatus (Bloch), experimentally infected with the specific Aphanomyces fungus associated with epizootic ulcerative syndrome (EUS) at different temperatures. J. Fish Dis. 18, 41-47. https://doi.org/10.1111/j.1365-2761.1995.tb01264.x

Chondar, S., Rao, P., 1996. Epizootic ulcerative syndrome disease to fish and its control: A review, in: World Aquaculture. World Aquaculture Society, Bangkok, Thailand, p. 77.

Choongo, K., Hang'ombe, B., Samui, K.L., Syachaba, M., Phiri, H., Maguswi, C., Muyangaali, K., Bwalya, G., Mataa, L., 2009. Environmental and climatic factors associated with epizootic ulcerative syndrome (EUS) in fish from the Zambezi floodplains, Zambia. Bull. Environ. Contam. Toxicol. 83, 474-8. https://doi.org/10.1007/s00128-009-9799-0

Coates, D., Nunn, M., Uwate, K., 1989. Epizootic ulcerative disease of freshwater fish in Papua New Guinea. Sci N Guin 15, 1-11.

Costa, H., Wijeyaratne, M., 1989. Epidemiology of epizootic ulcerative syndrome occuring for the first time among fish in Sri Lanka. J App Ichthyol 1, 48-52.

Cruz-lacierda, E., Shariff, M., 1995. Experimental transmission of Epizootic ulcerative syndrome (EUS) in snakehead (ophicephalus striatus), in: Shariff, M., Arthur, J., Subasinghe, R.P. (Eds.), Diseases in Asian Aquaculture II. Fish Health Section, Asian Fisheries Society, Manila, Philippines, pp. 327-336.

Das, M.K., Das, R.K., 1993. A review of the fish disease epizootic ulcerative syndrome in India. Environ. Ecol. 11, 134-145.

Deng, G., Li, S., Xie, J., Bai, J., Chen, K., Ma, D., Jiang, X., Lao, H., Yu, L., 2011. Characterization of a ranavirus isolated from cultured largemouth bass (Micropterus salmoides) in China. Aquaculture 312, 198-204. https://doi.org/10.1016/J.AQUACULTURE.2010.12.032

Devaraja, G., Shankar, K.M., Mohan, C. V., 2004. Monoclonal antibody-based immunodot test for epizootic ulcerative syndrome pathogen, Aphanomyces invadans. Curr. Sci. 87, 289-291.

Dhanaraj, M., Haniffa, M.A.K., Ramakrishnan, M.C., Singh, A.S.V., 2008. Microbial flora from the Epizootic Ulcerative Syndrome (EUS) infected murrel Channa striatus (Bloch, 1797) in Tirunelveli region. Turkish J. Vet. Anim. Sci. 32, 221-224.

Dick, M.W., Vick, M.C., Gibbings, J.G., Hedderson, T.A., Lopez Lastra, C.C., 1999. 18S rDNA for species of Leptolegnia and other Peronosporomycetes: justification for the subclass taxa Saprolegniomycetidae and Peronosporomycetidae and division of the Saprolegniaceae sensu lato into the Leptolegniaceae and Saprolegniaceae. Mycol. Res. 103, 1119-1125. https://doi.org/10.1017/S0953756299008643

Diéguez-Uribeondo, J., Cerenius, L., Söderhäll, K., 1994. Repeated zoospore emergence in Saprolegnia parasitica. Mycol. Res. 98, 810-815. https://doi.org/10.1016/S0953-7562(09)810605

Diéguez-Uribeondo, J., García, M.A., Cerenius, L., Kozubíková, E., Ballesteros, I., Windels, C., Weiland, J., Kator, H., Söderhäll, K., Martín, M.P., 2009. Phylogenetic relationships among plant and animal parasites, and saprotrophs in Aphanomyces (Oomycetes). Fungal Genet. Biol. 46, 365-376. https://doi.org/10.1016/j.fgb.2009.02.004

Diéguez-Uribeondo, J., Gierz, G., Bartnicki-García, S., 2004. Image analysis of hyphal morphogenesis in Saprolegniaceae (Oomycetes). Fungal Genet. Biol. 41, 293-307. https://doi.org/10.1016/j.fgb.2003.10.012

Dykstra, M., Noga, E., Levine, J., Moye, D., Hawkins, J., 1986. Characterization of the Aphanomyces species involved with ulcerative mycosis (UM) in menhaden. Mycologia 78, 664-672.

EFSA Panel on Animal Health and Welfare, 2011. Scientific opinion on epizootic ulcerative syndrome. EFSA J 9, 2387.

Egusa, S., Masuda, N., 1971. A new fungal disease of Plecoglossus altivelis. Fish Pathol. 6, 41-46.

El-Matbouli, M., Saleh, M., Soliman, H., 2014. Biosecurity risks associated with epizootic ulcerative 
syndrome and iridovirus in ornamental fish imported into the European Union. Vet. Rec. 174, 303. https://doi.org/10.1136/vr.102219

Ernst, R., Ejsing, C.S., Antonny, B., 2016. Homeoviscous Adaptation and the Regulation of Membrane Lipids. J. Mol. Biol. 428, 4776-4791. https://doi.org/10.1016/J.JMB.2016.08.013

FAO, 2009. Report of the international emergency disease investigation task force on a serious finfish disease in Southern Africa. Food and Agriculture Organization of the United Nations, Rome.

Frerichs, G.N., Millar, S.D., Alexander, M., 1989. Rhabdovirus Infection of Ulcerated Fish in SouthEast Asia, in: Ahne, W., Kurstak, E. (Eds.), Viruses of Lower Vertebrates. Springer-Verlag, Heidelberg, Germany, pp. 394-410.

Ganapathi, M.N., Rajesh, K.M., Sahoo, A.K., Shankar, K.M., 2008. Monoclonal antibody-based detection of Aphanomyces invadans for surveillance and prediction of epizootic ulcerative syndrome (EUS) outbreak in fish, in: Bondad-Reantaso, M.G., Mohan, C.V., Crumlish, M., Subasinghe, R.P. (Eds.), Diseases in Asian Aquaculture VI. Fish Health Section, Asian Fisheries Society, Manila, Philippines, pp. 157-168.

Gleason, F.H., Marano, A. V., Lilje, O., Lange, L., 2018. What has happened to the "aquatic phycomycetes" (sensu Sparrow)? Part I: A brief historical perspective. Fungal Biol. Rev. 32, $26-$ 33. https://doi.org/10.1016/J.FBR.2017.09.001

Go, J., Marsh, I., Gabor, M., Saunders, V., Reece, R., Frances, J., Boys, C., Gabor, L., 2012. Detection of Aphanomyces invadans and epizootic ulcerative syndrome in the Murray-Darling drainage. Aust. Vet. J. 90, 513-514. https://doi.org/10.1111/j.1751-0813.2012.01012.x

Gomo, C., Hanyire, T., Makaya, P., Sibanda, S., 2016. Outbreak of epizootic ulcerative syndrome (EUS) in Seranochromis robustus fish spesies in Darwendale dam, Zimbabwe. African J. Fish. Sci. 4, 204-205.

Gozlan, R.E., Andreou, D., Asaeda, T., Beyer, K., Bouhadad, R., Burnard, D., Caiola, N., Cakic, P., Djikanovic, V., Esmaeili, H.R., Falka, I., Golicher, D., Harka, A., Jeney, G., Kováč, V., Musil, J., Nocita, A., Povz, M., Poulet, N., Virbickas, T., Wolter, C., Serhan Tarkan, A., Tricarico, E., Trichkova, T., Verreycken, H., Witkowski, A., Guang Zhang, C., Zweimueller, I., Robert Britton, J., 2010. Pan-continental invasion of Pseudorasbora parva: towards a better understanding of freshwater fish invasions. Fish Fish. 11, 315-340. https://doi.org/10.1111/j.14672979.2010.00361.x

Gozlan, R.E., Marshall, W.L., Lilje, O., Jessop, C.N., Gleason, F.H., Andreou, D., 2014. Current ecological understanding of fungal-like pathogens of fish: what lies beneath? Front. Microbiol. 5, 62. https://doi.org/10.3389/fmicb.2014.00062

Haines, A.K., 1983. Fish fauna and ecology, in: Petr, T. (Ed.), The Purari Tropical Environment of High Rainfall River Basin. Hague: Dr W. Junk, pp. 367-384.

Haniffa, M.A., Dhasarathan, P., Dhanuskodi, V., 2011. Evaluation of immunostimulant potential of Solanum nigrum L. using fish, Etroplus suratensis challenged with Aphanomyces invadens. Int. J. Pharma Bio Sci. 2, 429-437.

Hanjavanit, C., Suda, H., Hatai, K., 1997. Mycotic granulomatosis found in two species of ornamental fishes imported from Singapore. Mycoscience 38, 433-436.

Hargis, W.J., 1985. Quantitative effects of marine diseases on fish and shellfish populations. Trans North Am Wildl Nat Resour Conf 50, 608-640.

Harikrishnan, R., Balasundaram, C., Bhuvaneswari, R., 2005. Restorative effect of Azadirachta indicab aqueous leaf extract dip treatment on haematological parameter changes in Cyprinus carpio (L.) experimentally infected with Aphanomyces invadans fungus. J. Appl. Ichthyol. 21, 410-413. https://doi.org/10.1111/j.1439-0426.2005.00614.x

Harikrishnan, R., Balasundaram, C., Dharaneedharan, S., Moon, Y.G., Kim, M.C., Kim, J.S., Heo, M.S., 2009. Effect of plant active compounds on immune response and disease resistance in cirrhina mrigala infected with fungal fish pathogen, Aphanomyces invadans. Aquac. Res. 40, 1170-1181. https://doi.org/10.1111/j.1365-2109.2009.02213.x

Harikrishnan, R., Balasundaram, C., Heo, M., 2010. Supplementation Diet Containing Probiotics , Herbal And Azadirachtin On Hematological And Biochemical Changes In Cirrhina mrigala Against Aphanomyces invadans. Fish. Aquac. J. 2010, 1-11.

Hart, D., 1997. Development of diagnostic systems for the study of the molecular epidemiology and taxonomy of the Aphanomyces fungus associated with EUS of tropical and freshwater fishes (No. Final Report of DFID Research Project R5902Cb), 1st October 1993 to 31st March 1997.

Hatai, K., Nakamura, K., Rha, S.A., Yuasa, K., Wada, S., 1994. Aphanomyces Infection in Dwarf Gourami(Colisa lalia). Fish Pathol. 29, 95-99. https://doi.org/10.3147/jsfp.29.95

Hawke, J.P., Grooters, A.M., Camus, A.C., 2003. Ulcerative Mycosis Caused by Aphanomyces invadans in Channel Catfish, Black Bullhead, and Bluegill from Southeastern Louisiana. J. 
Aquat. Anim. Health 15, 120-127. https://doi.org/10.1577/H02-039

Hedrick, R.P., Eaton, W.D., Fryer, J.L., Groberg, J.W.G., Boonyaratapalin, S., 1986. Characteristics of a birnavirus isolated from cultured sand goby Oxyeleotris marmoratus. Dis. Aquat. Org. 1, 219225.

Huchzermeyer, C.F., Huchzermeyer, K.D.A., Christison, K.W., Macey, B.M., Colly, P.A., Hang'ombe, B.M., Songe, M.M., 2018. First record of epizootic ulcerative syndrome from the Upper Congo catchment: An outbreak in the Bangweulu swamps, Zambia. J. Fish Dis. 41, 87-94. https://doi.org/10.1111/jfd.12680

Huchzermeyer, K.D.A., Van der Waal, B.C.W., 2012. Epizootic ulcerative syndrome: Exotic fish disease threatens Africa's aquatic ecosystems. J. S. Afr. Vet. Assoc. 83, 1-6.

Hussein, M.M.A., Wada, S., Hatai, K., Yamamoto, A., 2000. Antimycotic activity of eugenol against selected water molds. J. Aquat. Anim. Health 12, 220-223. https://doi.org/10.1577/15488667(2000)012<0224:AAOEAS>2.0.CO;2

Innocent, B.X., Fathima, M.S.A., Sivagurunathan, A., 2011. Haematology of cirrhinus mrigala fed with vitamin c supplemented diet and post challenged by aphanomyces invadens. J. Appl. Pharm. Sci. 1, 141-144.

Iqbal, M.M., Tajima, K., Sawabe, T., Nakano, K., Ezura, Y., 1998. Genotypic Identification of Motile Aeromonads Asian Isolated Countries from with Epizootic Ulcerative Syndrome in Southeast epizootic ulcerative syndrome ( EUS ) in Southeast Asia countries. Fish Pathol. 33, 255-263.

Jawahar, S., Nafar, A., Vasanth, K., Musthafa, M.S., Arockiaraj, J., Balasundaram, C., Harikrishnan, R., 2016. Dietary supplementation of Zeolite on growth performance, immunological role, and disease resistance in Channa striatus against Aphanomyces invadans. Fish Shellfish Immunol. 51, 161-169. https://doi.org/10.1016/j.fsi.2016.02.019

John, K.R., George, M.R., 2012. Viruses associated with epizootic ulcerative syndrome: An update. Indian J. Virol. 23, 106-113. https://doi.org/10.1007/s13337-012-0108-x

Jothy, A., 1981. Preliminary report on the outbreak of wabak kudison freshwater fish in paddy growing areas in Peninsular Malaysia, Report to Ministry of Agriculture, Malaysia, December,1981,17pp.

Kamilya, D., Baruah, A., 2014. Epizootic ulcerative syndrome (EUS) in fish: History and current status of understanding. Rev. Fish Biol. Fish. 24, 369-380. https://doi.org/10.1007/s11160-013-9335-5

Kanchanakhan, S., 1996. Epizootic ulcerative syndrome (EUS): a new look at the old story. AAHRI Newsl Aquat Anim Heal. Res Inst 5, 2-3.

Kar, D., 2016. Epizootic Ulcerative Fish Disease Syndrome. Academic Press. https://doi.org/10.1016/B978-0-12-802504-8.00012-2

Kiryu, Y., Blazer, V.S., Vogelbein, W.K., Kator, H., Shields, J.D., 2005. Factors influencing the sporulation and cyst formation of Aphanomyces invadans, etiological agent of ulcerative mycosis in Atlantic menhaden, Brevoortia tyrannus. Mycologia 97, 569-575. https://doi.org/10.3852/mycologia.97.3.569

Kiryu, Y., Shields, J.D., Vogelbein, W.K., Zwerner, D.E., Kator, H., Blazer, V.S., 2002. Induction of skin ulcers in Atlantic menhaden by injection and aqueous exposure to the zoospores of Aphanomyces invadans. J. Aquat. Anim. Health 14, 11-24. https://doi.org/10.1577/15488667(2002)014<0011:IOSUIA>2.0.CO;2

Kiziewicz, B., Zdrojkowska, E., Gajo, B., Godlewska, A., Muszynska, E., Mazalska, B., 2011. Occurrence of fungi and fungus-like organisms in the Horodnianka River in the vicinity of Bialystok, Poland. Wiad. Parazytol. 57, 159-164.

Leclerc, M.C., Guillot, J., Deville, M., 2000. Taxonomic and phylogenetic analysis of Saprolegniaceae (Oomycetes) inferred from LSU rDNA and ITS sequence comparisons. Antonie Van Leeuwenhoek 77, 369-377. https://doi.org/10.1023/A:1002601211295

Lian, C.X., 1990. Peoples Republic of China report, in: Phillips, M.J., Keddie, H.G. (Eds.), Regional Research Programme on Relationships between Epizootic Ulcerative Syndrome in Fish and the Environment. Network of Aquaculture Centres in Asia-Pacific, Bangkok, pp. 13-26.

Lilley, J., Hart, D., Panyawachira, V., Kanchanakhan, S., Chinabut, S., Söderhäll, K., Cerenius, L., 2003. Molecular characterization of the fish pathogenic fungus Aphanomyces invadans. J. Fish Dis. 26, 263-275.

Lilley, J.H., Frerichs, G.N., 1994. Comparison of rhabdoviruses associated with epizootic ulcerative syndrome (EUS) with respect to their structural proteins, cytopathology and serology. J. Fish Dis. 17, 513-522. https://doi.org/10.1111/j.1365-2761.1994.tb00246.x

Lilley, J.H., Hart, D., Panyawachira, V., Kanchanakhan, S., Chinabut, S., Söderhäll, K., Cerenius, L., 2003. Molecular characterization of the fish-pathogenic fungus Aphanomyces invadans. J. Fish Dis. 26, 263-75.

Lilley, J.H., Inglis, V., 1997. Comparative effects of various antibiotics, fungicides and disinfectants on 
Aphanomyces invaderis and other saprolegniaceous fungi. Aquac. Res. 28, 461-469. https://doi.org/10.1046/j.1365-2109.1997.00800.x

Lilley, J.H., Phillips, M.J., Tonguthai, K., 1992. A review of epizootic ulcerative syndrome (EUS) in Asia. Aquatic Animal Health Research Institute and Network of Aquaculture Centres in AsiaPacific, Jatujak, Bangkok.

Lilley, J.H., Roberts, R.J., 1997. Pathogenicity and culture studies comparing the Aphanomyces involved in epizootic ulcerative syndrome (EUS) with other similar fungi. J. Fish Dis. 20, 135144. https://doi.org/10.1046/j.1365-2761.1997.d01-116.x

Lio-Po, G.D., Traxler, G.S., Albright, L.J., Leaño, E.M., 2000. Characterization of a virus obtained from snakeheads Ophicephalus striatus with epizootic ulcerative syndrome (EUS) in the Philippines. Dis. Aquat. Organ. 43, 191-198. https://doi.org/10.3354/dao043191

Llobrera, A., Gacutan, R., 1987. Aeromonas hydrophila associated with ulcerative disease epizootic in Laguna de Bay, Philippines. Aquaculture 67, 273-278.

Lumanlam-Mayo, S.C., Callinan, R.B., Paclibare, J.O., Catap, E.S., Fraser, G.C., 1997. Epizootic ulcerative syndrome (EUS) in rice-fish culture systems: an overview of field experiments 19931995, in: Flegel, T.W., MacRae, I.H. (Eds.), Diseases in Asian Aquaculture III. Fish Health Section, Asian Fisheries Society, Manila, The Philippines, pp. 129-138.

Majeed, M., Kumar, G., Schlosser, S., El-Matbouli, M., Saleh, M., 2017. In vitro investigations on extracellular proteins secreted by Aphanomyces invadans, the causative agent of epizootic ulcerative syndrome. Acta Vet. Scand. 59, 78. https://doi.org/10.1186/s13028-017-0347-3

Makkonen, J., Vesterbacka, A., Martin, F., Jussila, J., Diéguez-Uribeondo, J., Kortet, R., Kokko, H., 2016. Mitochondrial genomes and comparative genomics of Aphanomyces astaci and Aphanomyces invadans. Sci. Rep. 6. https://doi.org/10.1038/srep36089

McKenzie, R.A., Hall, W.T.K., 1976. Dermal ulceration of mullet (Mugil cephalus). J Aust Vet 52, 230231.

Miles, D.J.C., Polchana, J., Lilley, J.H., Kanchanakhan, S., Thompson, K.D., Adams, A., 2001. Immunostimulation of striped snakehead Channa striata against epizootic ulcerative syndrome. Aquaculture 195, 1-15. https://doi.org/10.1016/S0044-8486(00)00529-9

Miles, D.J.C., Thompson, K.D., Lilley, J.H., Adams, A., 2003. Immunofluorescence of the epizootic ulcerative syndrome pathogen, Aphanomyces invadans, using a monoclonal antibody. Dis. Aquat. Organ. 55, 77-84. https://doi.org/10.3354/dao055077

Mines, A., Baluyot, E., 1986. Recent findings on the fish disease in Laguna Lake. PCARRD Monit. 14, $4-5$.

Oidtmann, B., 2012. Review of Biological Factors Relevant to Import Risk Assessments for Epizootic Ulcerative Syndrome (Aphanomyces invadans). Transbound. Emerg. Dis. 59, 26-39. https://doi.org/10.1111/j.1865-1682.2011.01241.x

OIE, 2017. Infection with Aphanomyces invadans (Epizootic Ulcerative Syndrome ), in: Manual of Diagnostic Tests for Aquatic Animals. OIE, pp. 1-14.

OIE, 2009. Epizootic Ulcerative Syndrome, in: Manual of Diagnostic Tests for Aquatic Animals. pp. 188-199.

Olson, L.W., Cerenius, L., Lange, L., Söderhäll, K., 1984. The primary and secondary spore cyst of Aphanomyces (Oomycetes, Saprolegniales). Nord. J. Bot. 4, 681-696. https://doi.org/10.1111/j.1756-1051.1984.tb01994.x

Pagrut, N.K., Ganguly, S., Jaiswal, V., Singh, C., 2017. An overview on epizootic ulcerative syndrome of fishes in India: A comprehensive report. J. Entomol. Zool. Stud. 5, 1941-1943.

Pathiratne, A., Rajapakshe, W., 1998. Hematological changes associates with epizootic ulcerative syndrome in the Asian Cichlid fish, Etroplus suratensis. Asian Fish. Sci. 11, $203-211$.

Phadee, P., Kurata, O., Hatai, K., 2004. A PCR Method for the Detection of Aphanomyces piscicida. Fish Pathol. 39, 25-31. https://doi.org/10.3147/jsfp.39.25

Phillips, M.J., 1989. A report on the NACA workshop on the regional research programme on ulcerative syndrome in fish and the environment. Network of Aquaculture Centres in AsiaPacific, lloilo city, Bangkok.

Podeti, K.R., Benarjee, G., 2017. Haematological changes in South Indian fresh water murrel, Channa punctatus have both EUS and A. hydrophila infection. J. Parasit. Dis. 41, 329-335. https://doi.org/10.1007/s12639-016-0798-x

Podeti, K.R., Benarjee, G., 2015. Haematological Changes In Fresh Water Fish, Channa striatus Diagnosed with the Epizootic Ulcerative Syndrome (EUS). Int. J. Adv. Biotechnol. Res. 6, 238244.

Pradhan, P.K., Mohan, C. V, Shankar, K.M., Kumar, B.M., 2010. Injection of forty-five day old fingerlings of common carp with zoospores of Aphanomyces invadans leads to histopathological 
lesions suggestive of epizootic ulcerative syndrome (EUS). Asian Fish. Sci. 23, 321-328.

Pradhan, P.K., Mohan, C. V, Shankar, K.M., Kumar, B.M., 2008. Susceptibility of fingerlings of Indian major carps to Aphanomyces invadans. Asian Fish. Sci. 21, 369-375.

Pradhan, P.K., Rathore, G., Sood, N., Swaminathan, T.R., Yadav, M.K., Verma, D.K., Chaudhary, D.K., Abidi, R., Punia, P., Jena, J.K., 2014. Emergence of epizootic ulcerative syndrome: Largescale mortalities of cultured and wild fish species in Uttar Pradesh, India. Curr. Sci. 106, 17111718.

Qureshi, T.A., Chauhan, R., Mastan, S.A., 2001. Haematological investigations on fishes infested with fungal growth. J. Environ. Biol. 22, 273-276.

Rab, A., Afzal, M., Akhtar, N., Barlas, A., Qayyum, M., 2001. Incidence of epizootic ulcerative syndrome (EUS) in freshwater fishes in the endemic area of Punjab, Pakistan. Bangladesh J. Fish. Res. 5, 45-52.

Reungprach, H., Boonyaratpalin, S., Supamatya, K., Kesornchandra, J., Polsheivin, W., Sadvakdee, J., 1983. Special report of the fish disease outbreak committee in Thailand. Ministry of Agriculture and Cooperatives, Thailand.

Roberts, R., Macintosh, D., Tonguthai, K., Boonyaratpalin, S., Tayaputch, N., Phillips, M., SD, M., 1986. Field and laboratory investigations into ulcerative fish diseases in the Asia-Pacific region, Technical report of FAO project TCP/RAS/4508. Bangkok, Thailand.

Roberts, R., Wooten, R., MacRae, I., Millar, S., Struthers, W., 1989. Ulcerative disease survey, Bangladesh., Final report to the Government of Bangladesh and the overseas Development Administration. Institute of Aquaculture, Stirling University, UK.

Roberts, R.J., Frerichs, G.N., Tonguthai, K., Chinabut, S., 1994. Epizootic ulcerative syndrome of farmed and wild fishes: A review, in: Muir, J., Roberts, R.J. (Eds.), Recent Advances in Aquaculture. Blackwell Science, pp. 207-239.

Roberts, R.J., Willoughby, L.G., Chinabut, S., 1993. Mycotic aspects of epizootic ulcerative syndrome (EUS) of Asian fishes. J. Fish Dis. 16, 169-183. https://doi.org/10.1111/j.13652761.1993.tb01248.x

Robideau, G.P., De Cock, A.W.A.M., Coffey, M.D., Voglmayr, H., Brouwer, H., Bala, K., Chitty, D.W., Désaulniers, N., Eggertson, Q.A., Gachon, C.M.M., Hu, C.-H., Küpper, F.C., Rintoul, T.L., Sarhan, E., Verstappen, E.C.P., Zhang, Y., Bonants, P.J.M., Ristaino, J.B., Lévesque, C.A., 2011. DNA barcoding of oomycetes with cytochrome $c$ oxidase subunit I and internal transcribed spacer. Mol. Ecol. Resour. 11, 1002-11. https://doi.org/10.1111/j.1755-0998.2011.03041.x

Rukyani, A., 1994. Status of Epizootic ulcerative disease in Indonesia, in: Roberts, R., Campbell, B., MacRae, I. (Eds.), Proceedings of the ODA Regional Seminar on Epizootic Ulcerative Syndrome. Aquatic Animal Health Research Institute, Bangkok, pp. 68-75.

Saha, D., Pal, J., 2000. Bacterial studies on fishes affected with epizootic ulcerative syndrome. Asian Fish. Sci. 13, 343-355.

Saikia, D., Kamilya, D., 2012. Immune responses and protection in catla (Catla catla) vaccinated against epizootic ulcerative syndrome. Fish Shellfish Immunol. 32, 353-359. https://doi.org/10.1016/j.fsi.2011.11.030

Saitanu, K., Wongsawang, S., Sunyasootcharee, B., Sahaphong, S., 1986. Snakehead fish virus isolation and pathogenicity studies [Thailand], in: McLean, J., Dizon, L., Hosillios, L. (Eds.), Proceeding of the First Asian Fisheries Forum. Manila, Philippines, pp. 327-330.

Sanaullah, M., Hjeltnes, B., Ahmed, A.T.., 2001. The Relationship of Some Environmental Factors and the Epizootic Ulcerative Syndrome Outbreaks in Beel Mahmoodpur, Faridpur, Bangladesh. Asian Fish. Sci. 14, 301-315.

Shaalan, M., El-Mahdy, M., El-Matbouli, M., 2017. Zinc oxide nanoparticles as a novel tool to combat yersinia ruckeri and aphanomyces invadans. J. Comp. Pathol. 156, 74.

Shanthi Mari, L.S., Jagruthi, C., Anbazahan, S.M., Yogeshwari, G., Thirumurugan, R., Arockiaraj, J., Mariappan, P., Balasundaram, C., Harikrishnan, R., 2014. Protective effect of chitin and chitosan enriched diets on immunity and disease resistance in Cirrhina mrigala against Aphanomyces invadans. Fish Shellfish Immunol. 39, 378-385. https://doi.org/10.1016/j.fsi.2014.05.027

Shariff, M., Law, A., 1980. An incidence of fish mortality in Bekok River, Johore, Malaysia, in: Proceedings of the International Symposium on Conservation Input from Life Sciences. Universiti Kebangsaan, Bangi, Selangor, Malaysia, pp. 153-162.

Sharma, P., Sihag, R.C., 2013. Pathogenicity test of bacterial and fungal fish pathogens in Cirrihinus mrigala infected with EUS disease. Pakistan J. Biol. Sci. 16, 1204-1207. https://doi.org/10.3923/pjbs.2013.1204.1207

Shrestha, G., 1994. Status of epizootic ulcerative syndrome (EUS) and its effect on aquaculture in Nepal, in: Roberts, R., Campbell, B., MacRae, I. (Eds.), Proceedings of the ODA Regional 
Seminar on Epizootic Ulcerative Syndrome. Aquatic Animal Health Research Institute, Bangkok, pp. 49-57.

Sosa, E.R., Landsberg, J.H., Stephenson, C.M., Forstchen, A.B., Vandersea, M.W., Litaker, R.W., 2007. Aphanomyces invadans and ulcerative mycosis in estuarine and freshwater fish in Florida. J. Aquat. Anim. Health 19, 14-26. https://doi.org/10.1577/H06-012.1

Srivastava, S., Sinha, R., Roy, D., 2004. Toxicological effects of malachite green. Aquat. Toxicol. 66, 319-29.

Subasinghe, R.P., 1993. Effects of controlled infections of Trichodina sp. on transmission of epizootic ulcerative syndrome (EUS) to naive snakehead, Ophicephalus striatus Bloch. J. Fish Dis. 16, 161-164. https://doi.org/10.1111/j.1365-2761.1993.tb00861.x

Subramanian, S., Chew-Lim, M., Chong, S.Y., Howe, J., Ngoh, G.H., Chan, Y.C., 1993. Molecular and electron microscope studies of infectious pancreatic necrosis virus from snakehead, in: IXth International Congress of Virology. Glasgow, UK, p. 368.

Svobodova, Z., Lloyd, R., Machova, J., Vykusova, B., 1993. Water quality and fish health. EIFAC Technical paper No. 54, Rome.

Takuma, D., Sano, A., Wada, S., Kurata, O., Hatai, K., 2010. A new species, Aphanomyces salsuginosus sp. nov., isolated from ice fish Salangichthys microdon. Mycoscience 51, 432-442. https://doi.org/10.1007/S10267-010-0058-3

Thampuran, N., Surendran, P.K., Mukundan, M.K., Gopakumar, K., 1995. Bacteriological Studies on Fish Affected by Epizootic Ulcerative Syndrome. Asian Fish. Sci. 8, 103-111.

Tonguthai, K., 1985. A preliminary account of ulcerative fish diseases in Indo-Pacific region. Bangkok.

Ulcerative Fish Disease Committee, 1983. Practical report of the Ulcerative Fish Disease Committee 1982-1983. Bangkok.

van West, P., 2006. Saprolegnia parasitica, an oomycete pathogen with a fishy appetite: new challenges for an old problem. Mycologist 20, 99-104. https://doi.org/10.1016/j.mycol.2006.06.004

Vandersea, M.W., Litaker, R.W., Yonnish, B., Sosa, E., Landsberg, J.H., Pullinger, C., Moon-Butzin, P., Green, J., Morris, J.A., Kator, H., Noga, E.J., Tester, P.A., 2006. Molecular assays for detecting Aphanomyces invadans in ulcerative mycotic fish lesions. Appl. Environ. Microbiol. 72, 1551-1557. https://doi.org/10.1128/AEM.72.2.1551-1557.2006

Wada, S., Rha, S., Kondoh, T., Suda, H., Hatai, K., Ishii, H., 1996. Histopathological Comparison between Ayu and Carp Artificially Infected with Aphanomyces piscicida. Fish Pathol. 31, 71-80. https://doi.org/10.3147/jsfp.31.71

Wada, S., Yuasa, K., Rha, S., Nakamura, K., Hatai, K., 1994. Histopathology of Aphanomyces infection in dwarf gourami (Colisa lalia). Fish Pathol. 29, 229-237.

Wattanavijarn, W., Torchy, C., Tangtronpiros, J., Kinkelin, P., 1988. Isolation of a Birnavirus belonging to Sp Serotype from South East Asia fishes. Bull Eur Ass Fish Pathol 8, 106-107.

Whittington, R.J., Chong, R., 2007. Global trade in ornamental fish from an Australian perspective: the case for revised import risk analysis and management strategies. Prev Vet Med 81, 92-116. https://doi.org/10.1016/j.prevetmed.2007.04.007

Willoughby, L.G., Roberts, R.J., Chinabut, S., 1995. Aphanomyces invaderis sp. nov., the fungal pathogen of freshwater tropical fish affected by epizootic ulcerative syndrome. J. Fish Dis. 18, 273-276. https://doi.org/10.1111/j.1365-2761.1995.tb00302.x

Wilson, K., Lo, K., 1992. Fish Disease in Hong Kong and the potential role of the veterinarian, in: 23rd Annual Conference of the International Association for Aquatic Animal Medicine (IAAAM). Hong Kong.

Xuan, T., 1990. Vietnam report, in: Phillips, M., Keddie, H. (Eds.), Regional Research Programme on Relationships between Epizootic Ulcerative Syndrome in Fish and the Environment. Network of Aquaculture Centres in Asia-Pacific, Bangkok.

Yadav, M.K., Pradhan, P.K., Sood, N., Chaudhary, D.K., Verma, D.K., Debnath, C., Sahoo, L., Chauhan, U.K., Punia, P., Jena, J.K., 2014. Innate immune response of Indian major carp, Labeo rohita infected with oomycete pathogen Aphanomyces invadans. Fish Shellfish Immunol. 39, 524-531. https://doi.org/10.1016/j.fsi.2014.06.005

Yogeshwari, G., Jagruthi, C., Anbazahan, S.M., Mari, L.S.S., Selvanathan, J., Arockiaraj, J., Dhayanithi, N.B., Ajithkumar, T.T., Balasundaram, C., Ramasamy, H., 2015. Herbal supplementation diet on immune response in Labeo rohita against Aphanomyces invadans. Aquaculture 437, 351-359. https://doi.org/10.1016/j.aquaculture.2014.12.024 
Tab. 1 EUS outbreaks worldwide including their first year of occurrence (see also Fig.

1).

\begin{tabular}{|c|c|c|}
\hline Country & Year of occurrence & Reference \\
\hline Japan & 1971 & (Egusa and Masuda, 1971) \\
\hline Australia & $1972 ; 2001$ & (Boys et al., 2012; McKenzie and Hall, 1976) \\
\hline Papua New Guinea & $1975-1976 ; 1982-1983$ & (Coates et al., 1989; Haines, 1983) \\
\hline Singapore & 1977,1997 & (Hanjavanit et al., 1997; Roberts et al., 1986) \\
\hline Malaysia & $1979-1980$ & (Jothy, 1981; Shariff and Law, 1980) \\
\hline Thailand & 1981 & $\begin{array}{l}\text { (Tonguthai, 1985; Ulcerative Fish Disease Committee, } \\
\text { 1983) }\end{array}$ \\
\hline China & 1982 & $($ Lian, 1990) \\
\hline Vietnam & 1983 & (Xuan, 1990) \\
\hline Lao PDR & 1983 & (Lilley et al., 1992) \\
\hline Myanmar & 1984 & (Lilley et al., 1992) \\
\hline Cambodia & 1984 & (Lilley et al., 1992) \\
\hline Philippines & 1985 & (Llobrera and Gacutan, 1987; Mines and Baluyot, 1986) \\
\hline Sri Lanka & 1987 & (Costa and Wijeyaratne, 1989) \\
\hline Bangladesh & 1988 & (Barua, 1994; Roberts et al., 1989) \\
\hline Hong Kong & 1988 & (Wilson and Lo, 1992) \\
\hline Nepal & 1989 & (Shrestha, 1994) \\
\hline Bhutan & 1989 & (Phillips, 1989) \\
\hline India & 1989; 1991 & (Das and Das, 1993) \\
\hline Indonesia & 1990 & (Rukyani, 1994) \\
\hline Pakistan & 1996 & (Kanchanakhan, 1996) \\
\hline USA & $1980 ; 1997 ; 1998$ & $\begin{array}{l}\text { (Blazer et al., 1999; Dykstra et al., 1986; Hargis, 1985; } \\
\text { Sosa et al., 2007) }\end{array}$ \\
\hline Africa & $\begin{array}{l}2006 ; 2007 ; 2010 ; 2012 ; \\
2014\end{array}$ & $\begin{array}{l}\text { (Andrew et al., 2008; EFSA Panel on Animal Health and } \\
\text { Welfare, 2011; FAO, 2009; Gomo et al., 2016; } \\
\text { Huchzermeyer et al., 2018; Huchzermeyer and Van der } \\
\text { Waal, 2012) }\end{array}$ \\
\hline Iraq & $2007-2008$ & (EFSA Panel on Animal Health and Welfare, 2011) \\
\hline Canada & 2010 & (EFSA Panel on Animal Health and Welfare, 2011) \\
\hline
\end{tabular}


Tab. 2 Repertoire of effector proteins of $\boldsymbol{A}$. invadans (FungiDB).

\begin{tabular}{lccc}
\hline Gene families & A. invadans & S. parasitica & P.infestans \\
\hline RXLR & 0 & 1 & 596 \\
Crinkler & 0 & 0 & 452 \\
NPP1-like proteins & 0 & 0 & 67 \\
Elicitin and elicitin like & 12 & 32 & 86 \\
Cutinase & 0 & 0 & 4 \\
Pectin methyl esterases & 1842 & 1955 & 1641 \\
Glycosyl hydrolase & 526 & 748 & 760 \\
$\quad$ Pectate lyases & 0 & 2 & 49 \\
$\quad$ Polygalaturonases & & & \\
PAN & 41 & 53 & 27 \\
CBEL & 0 & 0 & 4 \\
Ricin & 23 & 80 & 8 \\
Gal-Lectin-binding & 5193 & 6594 & 5452 \\
Jacalin-like lectin & 52 & 120 & 61 \\
Jacalin-like & 2 & 4 & 15 \\
Legume-like lectin & 52 & 120 & 61 \\
Legume-like & 3 & 3 & 3 \\
Disintegrin & 0 & 22 & 0 \\
Protease inhibitors,all & 182 & 209 & 317 \\
$\quad$ Serine protease & 54 & 47 & 65 \\
$\quad$ Metalloprotease & 37 & 39 & 38 \\
Cysteine protease & 67 & 81 & 59 \\
ABC transporter, all & 108 & 147 & 161 \\
Kinases & 35 & 39 & 34 \\
Notch protein & 12 & 21 & 1 \\
Haemolysin E & 0 & 5 & 0 \\
\hline
\end{tabular}


Tab. 3 Pathogens co-isolated with A. invadans from fish with EUS.

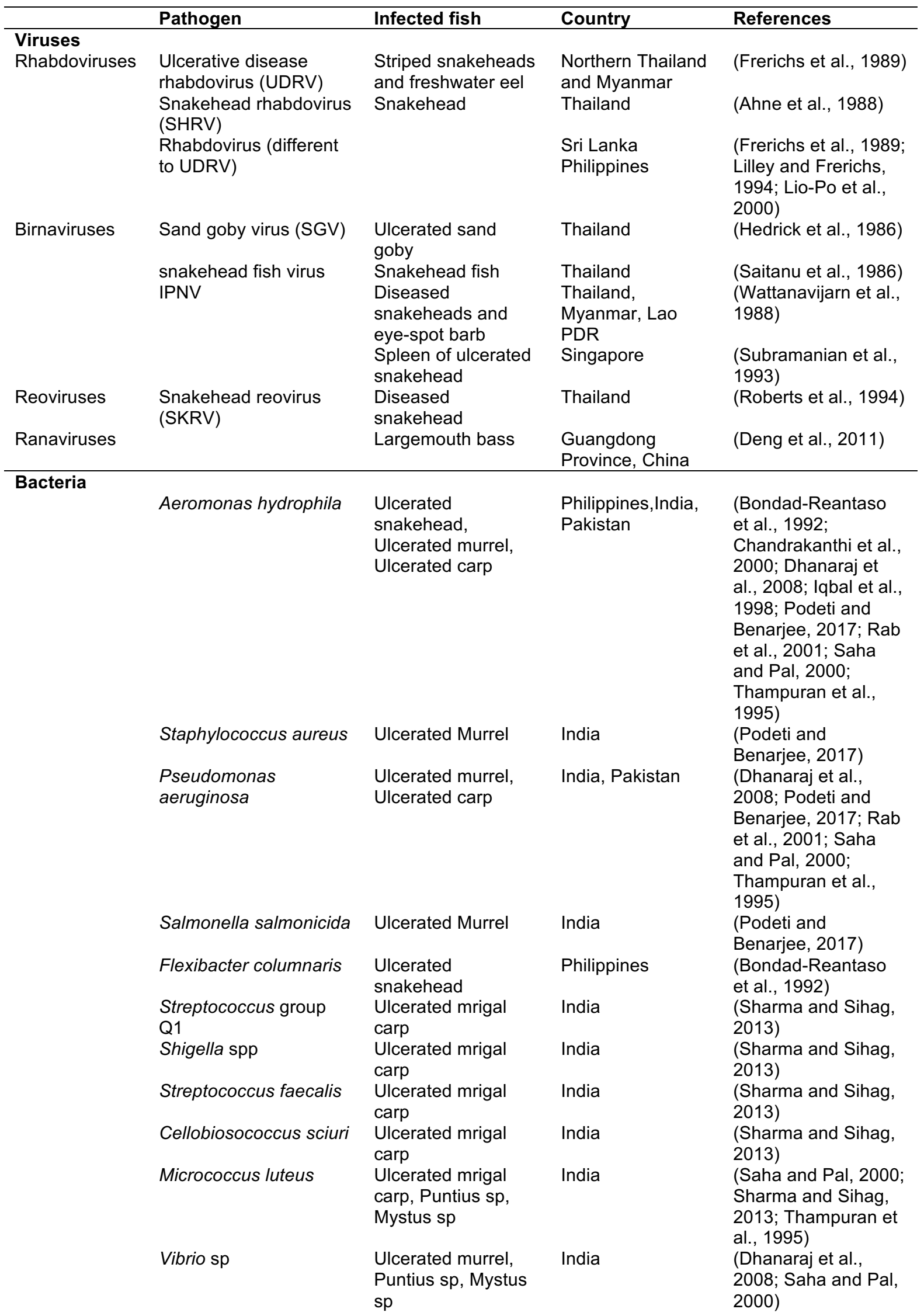




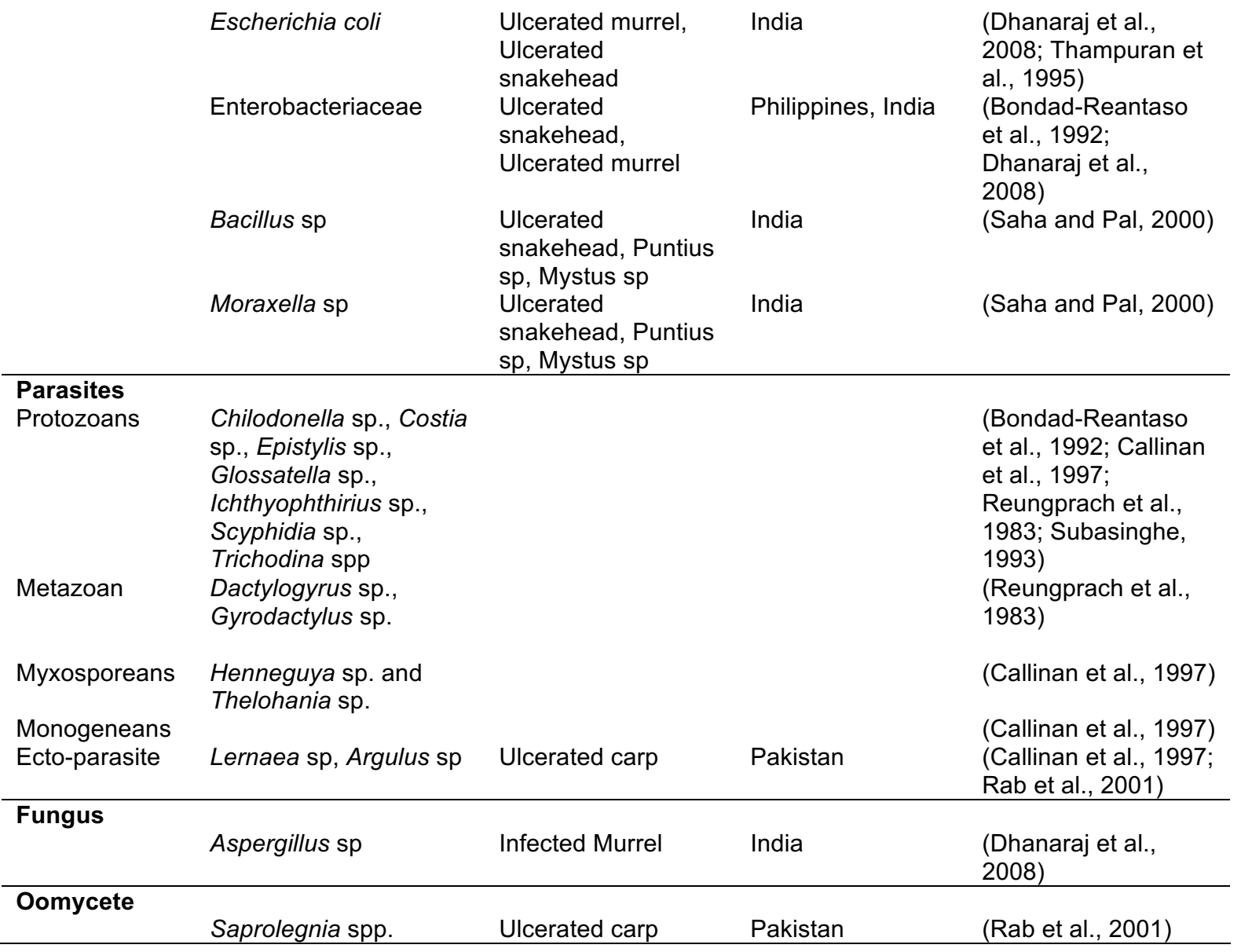


Tab. 4 Plant extracts effective against $\boldsymbol{A}$. invadans growth.

\begin{tabular}{lll}
\hline Genus & Species & Reference \\
\hline Herb & Piper betle & (Borisutpeth et al., 2009) \\
& Mammea siamensis & (Borisutpeth et al., 2009) \\
& Tamarindus indica & (Borisutpeth et al., 2009) \\
& Rosa spp & (Borisutpeth et al., 2009) \\
& Psidium guajava & (Borisutpeth et al., 2009; Campbell et al., 2001) \\
& Azadirachta indica & (Harikrishnan et al., 2010, 2009, 2005) \\
& Solanum nigrum & (Haniffa et al., 2011) \\
& Cassia fistula & (Borisutpeth et al., 2014) \\
& Rauvolfia tetraphylla & (Yogeshwari et al., 2015) \\
& Sonneratia alba & (Afzali and Wong, 2017) \\
\hline Mangrove plant & &
\end{tabular}




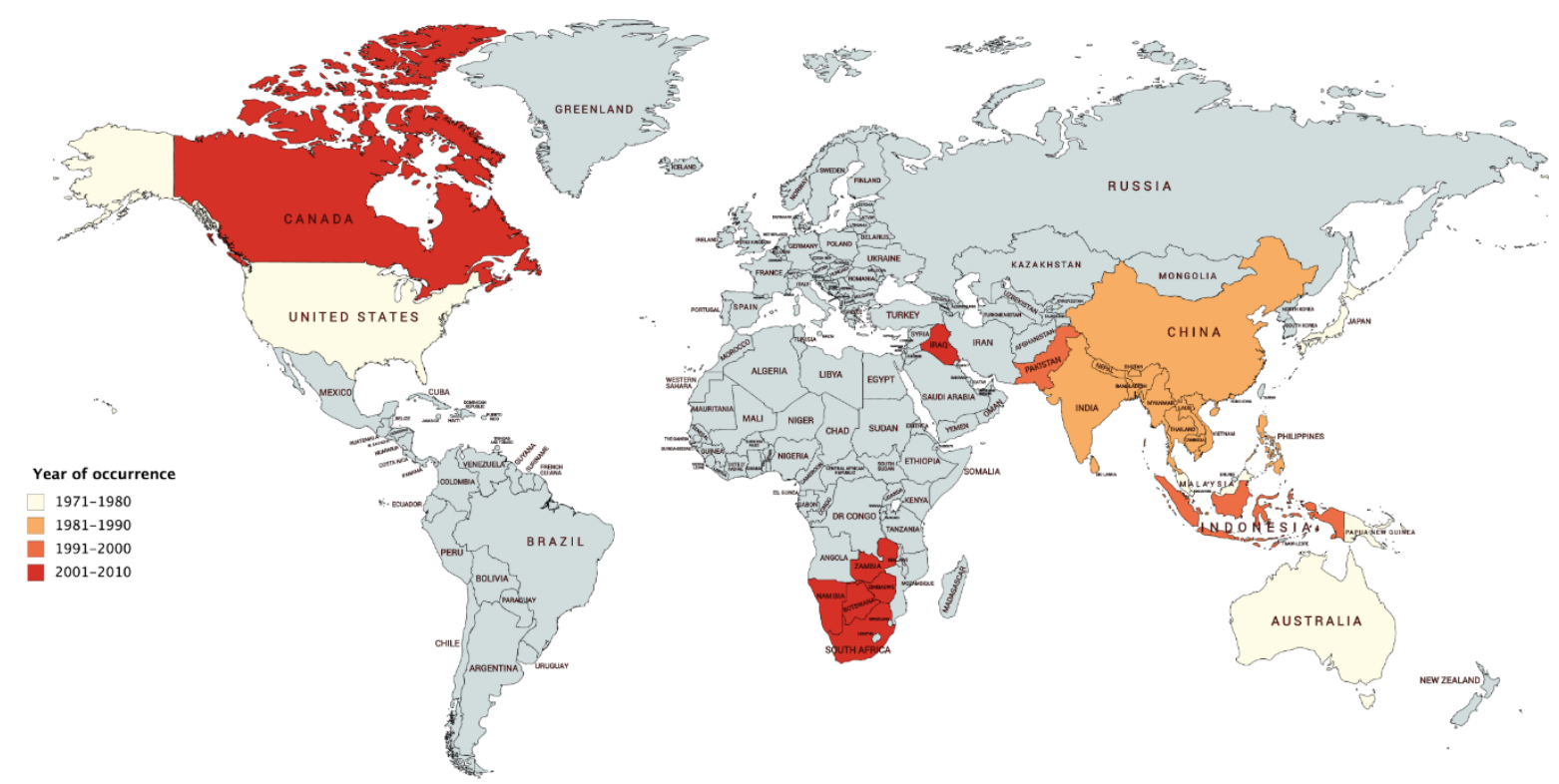

Fig. 1 First occurence of EUS outbreaks in fresh water fish worldwide. (ee also Tab. 1) Countries are labelled in colours according to the decade of their first $A$. invadans infection outbreak. The outbreaks started in the South-East of Asia and are now disseminating to all continents likely due to globall trading. 


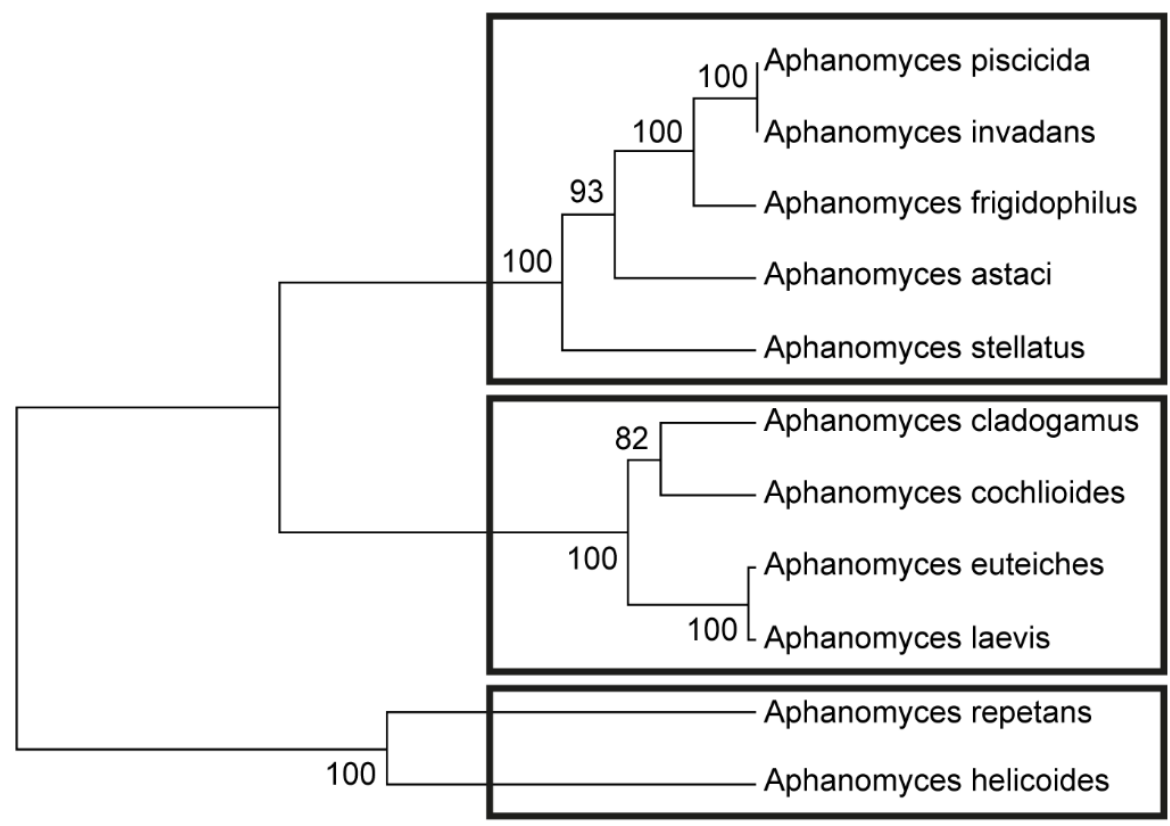

Animal

parasitic

lineage

Plant

parasitic

lineage

Saprotrophic/ opportunistic lineage

Fig. 2 Different lineages of Aphanomyces sp. infecting different groups of hosts. Phylogenetic tree is based on 5.8S ribosomal RNA gene from A. piscicida (AY283640), A. invadans (DQ403202), A. frigidophilus (AY647192), A. astaci (AY310501), A. stellatus (AY683888), A. cladogamus (AY353918), A. cochlioides (AY353911), A. euteiches (AY353901), A. laevis (AY283646), A. repetans (AY683889) and A.helicoides (AY310496). Phylogenetic tree was created with MEGA 7.0 and phylogeny was tested with the Bootstrap method (1000 bootstrap). 

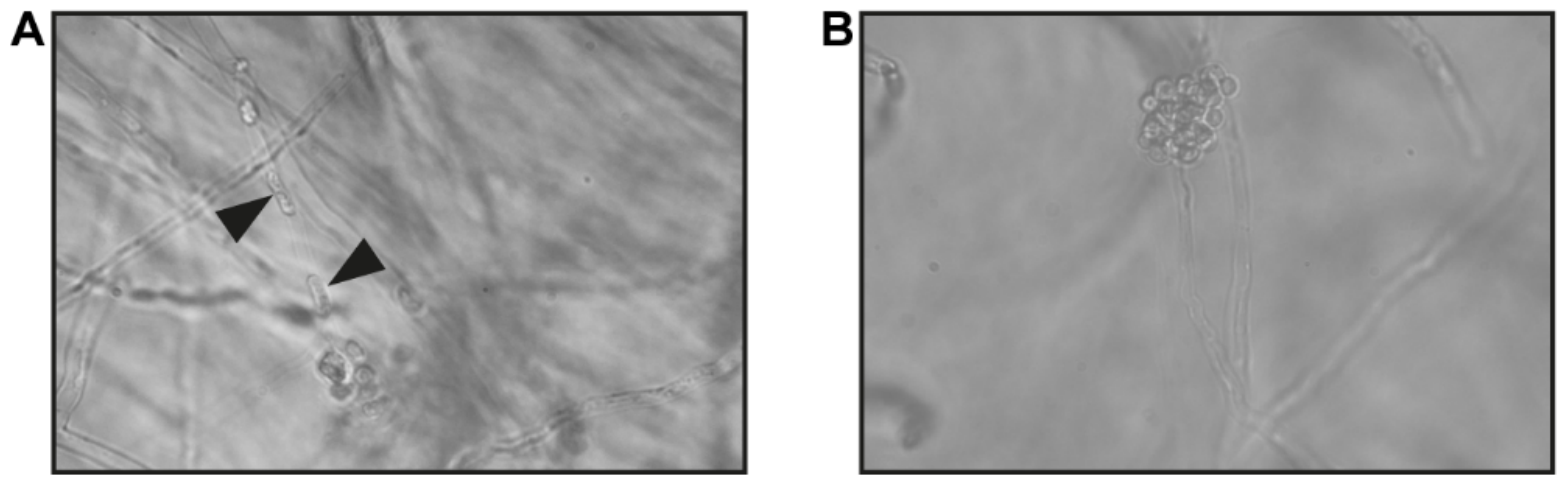

Fig. 3 Formation of achloid clusters by encysted primary zoospores at the hyphal tip. Similar to Aphanomyces salsuginosus also primary zoospores of $A$. invadans are transported in the hyphae (A, arrowheads) to form clusters at the hyphal tip from where secondary zoospores are released $(B)$.

\section{SUPPLEMENT}

Movie S1. Formation of secondary zoospores of $A$. invadans from clusters of primary cysts at hyphal tips. 